\title{
SPECIFIC COMPOSITION AND SEASONAL FLUCTUATION OF DESTRUCTIVE AND BENEFICIAL INSECT SPECIES INHABITING THREE MEDICINAL PLANTS IN ASSIUT GOVERNORATE
}

\author{
A. G. Ali, M. Z. Embarak and A. E. A. Ahmed \\ Plant Protection Res. Institute, Agricultural Research Center, Giza, Egypt
}

\begin{abstract}
:
Incidence and species composition of destructive and beneficial insect species inhabiting three medicinal plants namely; anise, Pimpinella anisum L.; caraway, Carum carvi L. and cumin, Cuminum cyminum $\mathrm{L}$. as well as the population fluctuation have been studied during the two growing seasons 2006/2007 and 2007/2008 at Abnoub district, Assiut Governorate, Egypt.

Data obtained cleared that 23 species belong to 21 genera, 18 families and 9 orders were associated with anise, caraway and cumin. Destructive species were more dominant comprising $52.17 \%$ than beneficial species representing $47.83 \%$ of the total species. The major component of destructive insects was Homompterus and Hemipterus insects, while Hemipterus and Hymenopterus insects for beneficial insects.

The highest number of insects was recorded on caraway followed by anise while cumin was the lowest one during the two seasons. Anise achieved the highest number of destructive insects, whereas caraway harbored the highest number of beneficial insects. The lowest number of destructive and beneficial insects was recorded on cumin. However, the number of beneficial insects was more than destructive insects on anise and caraway, in reverse with cumin plants. Destructive and beneficial insects were occurred in few numbers during February, but their peaks were recorded during April for the three medicinal plants.
\end{abstract}

\section{INTRODUCTION:}

The aromatic plants have a great demand both in Egypt and abroad, for its multiple uses. The demand for these plants is increasing continuously in many important fields e.g. medicinal cure, perfume production, soap and cosmetics, refreshing beverages and nutritious such as hibiscus, mint, anise, caraway and others. Also, it is used as spices such as, cumin, coriander, fennel fruits and in natural flavor and aroma additives in food industries, that in addition of its using as insecticides (Abou Zaid, 1988 and Rayadh, 2002).
Medicinal and aromatic plants cultivated areas reached the average of 57.4 thousand feddans during the period from 1990 to 2005 , representing $0.43 \%$ of the total cultivated areas at the Arab Republic of Egypt. Whereas, their total production value reached 396.715 million L.E. as an annual average at the same period. Exporting value reached 94.71 million L.E. representing approximately $6.08 \%$ from the total export value (Shabbara and Taha, 2007).

However, many destructive insect species may feed on the plants until physiological maturation is reached. This inevitably leads to eventual loss in the quantity and quality of pharmaceutical products. Also, beneficial 
insects such as, predators, parasitoids, pollinators and visitors could play an important role which affecting productivity of the crops.

A number of investigations have been surveyed the insects inhabiting different medicinal plants (Propov, 1972 and 1973; Tiwari and Joshi, 1974; Rashad, 1978; Giry, 1980; Mesbah et al., 1983; Ali, 1988; AbouElhagag,1989; Abdel-Moniem and AbdelWahab, 2006).

The aim of this work is to study the species composition and population fluctuation of destructive and beneficial insect species inhabiting anise, caraway and cumin plants. Results should provide basic information on occurrence of these species.

\section{MATERIALS AND METHODS:}

The experiment of this investigation was conducted at Abnoub district located $25 \mathrm{Km}$ northeast of Assiut city, during two consecutive seasons of 2006/2007 and 2007/2008. The medicinal plants (i.e., anise, caraway and cumin) were planted in the end of November. An area about half Feddan was chosen and divided into 12 plots. The three medicinal plants were distributed in a complete randomized blocks with four replicates each. Normal agriculture practices were carried out and no chemical pest control was done.

Successive samples were taken weekly starting from the second half of February using sweep net technique. Twenty five double strokes were taken from each replicate and transferred to the laboratory for inspection. Every captured sample was put in a glass jar containing sodium cyanide to kill the insects. Specimens of unidentified species were kept in vials containing $\mathbf{7 5 \%}$ ethyl alcohol for later identification. All specimens were classified to their respective orders, families, genera and species whenever possible.

The actual and average numbers of destructive and beneficial insects including predators, parasites, pollinators and visitors over the season of each medicinal plant species were determined to study the population fluctuation of these collections. Data were statistically analyzed by using (ANOVA) and means were compared using the least significant difference (LSD) at probability level of 0.05 .

\section{RESULTS AND DISCUSSION:}

\section{1-Species composition of destructive and beneficial insects species:}

A partial taxonomic list Table (1) illustrate the recovered orders, families, common names and scientific names of the destructive and the beneficial insects found on anise, caraway and cumin plants. Results revealed that 23 insect species belong to 18 families and 9 orders were collected from the three medicinal plants during the two seasons of study. Destructive insects comprised 12 species belong to 9 families and 6 orders. Homopterus and Heteropterus insects were the major component of catches composing (4) species for each. Beneficial insects compose 11 species of $\mathbf{1 0}$ families and 5 orders. Hemipterus and Hymenopterus were the major component of catches comprised (3) species for each. Destructive and beneficial insects represent $52.17 \%$ and $47.83 \%$, respectively of the total insects species on the three medicinal plants (anise, caraway and cumin). In harmony with the results of this work, Abdel-Moniem and Abdel-Wahab, 2006 were recorded fourteen phytophagous insect species and six insect predators on roselle plants, Hibiscus sabdariffa L. Also, the dominance percentage of destructive insect was found to be higher than those of the predators. 
Hussein and abdel-Aal, 1982 concluded that ten plants species including wild mustard and coriander were pollinated by 12 genera of bees belonging to 7 families.

Table (1): A partial taxonomic list of destructive and beneficial species collected from anise, caraway and cumin plants, at Abnoub district, Assiut Governorate, during 2007 and 2008 seasons

\begin{tabular}{|c|c|c|c|c|c|}
\hline No. & Order & Family & Common name & Scientific name & Specimen \\
\hline 1 & \multirow{2}{*}{ Coleoptera } & Coccinellidae & $\begin{array}{l}\text { Seven-spot } \\
\text { ladybird }\end{array}$ & $\begin{array}{c}\text { Coccinella septumpunctata } \\
\text { L. }\end{array}$ & Predator \\
\hline 2 & & Coccinellidae & $\begin{array}{c}\text { Scymnus lady } \\
\text { beetle }\end{array}$ & $\begin{array}{c}\text { Scymnus punctillum } \\
\text { Weise }\end{array}$ & Predator \\
\hline 3 & \multirow{3}{*}{ Diptera } & Agromyzidae & Leaf miner & Agromyza sajae Zeht & Destructive \\
\hline 4 & & Calliphoridae & Blue fly & Chrysoma regalis $\mathrm{F}$. & Pollinator, Visitor \\
\hline 5 & & Muscidae & House fly & Musca domestica $\mathrm{L}$. & Pollinator, Visitor \\
\hline 6 & \multirow{7}{*}{ Hemiptera } & Miridae & Campyloma bug & $\begin{array}{c}\text { Campylomma impicta } \\
\text { Wager }\end{array}$ & Destructive \\
\hline 7 & & Miridae & Plant bug & Phytocoris sp. & Destructive \\
\hline 8 & & Lygaeidae & Lygeid seed bug & $\begin{array}{c}\text { Nysius graminicola } \\
\text { Kolnati }\end{array}$ & Destructive \\
\hline 9 & & Rhopalidae & $\begin{array}{c}\text { Hyaline grass } \\
\text { bug }\end{array}$ & Liorhyssus hyalinus Fab & Destructive \\
\hline 10 & & Miridae & Predator bug & Deraeocoris sernus D\&S & Predator \\
\hline 11 & & Anthocoridae & Minat pirate bug & Orius albidipennis Recter & Predator \\
\hline 12 & & Nabidae & Predator bug & Nabis sp. & Predator \\
\hline 13 & \multirow{4}{*}{ Homoptera } & Cicadellidae & $\begin{array}{c}\text { Leaf hopper on } \\
\text { vegetable }\end{array}$ & Emposca decipiens Paoli & Destructive \\
\hline 14 & & Cicadellidae & $\begin{array}{c}\text { Green leaf } \\
\text { hopper }\end{array}$ & Emposca lypica Deber & Destructive \\
\hline 15 & & Aphididae & Cowpea aphid & Aphis craccivora Koch & Destructive \\
\hline 16 & & Aphididae & Cotton aphid & Aphis gossypii Clover & Destructive \\
\hline 17 & \multirow{3}{*}{ Hymenoptera } & Apididae & Honey bee & Apis spp. & Pollinator, Visitor \\
\hline 18 & & Andrenidae & Wild bee & Andirena spp. & Pollinator, Visitor \\
\hline 19 & & Aphillinidae & Parasite & Aphilinus sp. & Parasite \\
\hline 20 & Lipedoptera & lycaenidae & $\begin{array}{c}\text { Legume blue } \\
\text { butterfly }\end{array}$ & Cosmolyce baeticus $\mathbf{L}$. & Destructive \\
\hline 21 & Neuroptera & Chrysopdae & $\begin{array}{l}\text { Common green } \\
\text { lacewing }\end{array}$ & Chrysopa vulgaris Schn & Predator \\
\hline 22 & Orthoptera & Acididae & $\begin{array}{c}\text { Red wing } \\
\text { grasshopper }\end{array}$ & Acrotylus insubicus Scop & Destructive \\
\hline 23 & Thysanoptera & Thripidae & $\begin{array}{l}\text { Onion cotton } \\
\text { thrips }\end{array}$ & Thrips tabaci Lind & Destructive \\
\hline
\end{tabular}

\section{2-Population fluctuation of insects inhabiting anise, caraway and cumin:}

Data in Table (2) show weekly average of insects/25 double strokes of sweeping net associated with anise, caraway and cumin plants during 2006/2007 and 2007/2008 seasons.

It is evident from the results obtained that the average numbers of destructive and beneficial insects were higher in the second season (24.27 insects/25 double strokes) than in the first season (18.18 insects/25 double strokes). Caraway harbored the highest number of destructive and beneficial insects $\mathbf{( 3 0 . 3 8}$ insects/25 double strokes) followed by anise (26.22 insects/25 double strokes) while cumin was the lowest one $(7.08$ insects/25 double strokes). This result may be attributed to the pattern of the plant growth or to the proportional low infestation level of the pests in relation to the volume of green matter of the 
plant (Ali, 1988). Predators achieved the highest number of insects population (37.37 predators/25 double strokes) followed by destructive insects with significant difference (30.17 destructive insects/25 double strokes) then pollinators and visitors $(12.67 / 25$ double strokes) and lastly the parasitoids $(4.70$ parasites/25 double strokes).

Anise harbored the highest average number of destructive insects followed by caraway then cumin $(35.69$ and $44.27 ; 29.15$ and $38.54 ; 12.05$ and 21.33 insects/25 double strokes) during 2007 and 2008 seasons, respectively. On the other hand, caraway had the highest average number of beneficial insects followed by anise while cumin was the lowest one $\mathbf{7 1 . 0 3}$ and 104.33; 61.91 and $67.89 ; 8.32$ and 14.95 insects/25 double strokes) during 2007 and 2008 seasons, respectively. Hammoda, 1987 reported that the susceptibility of medicinal and aromatic plants to pest infestation could be governed by the availability of repellent substances in addition to certain physical character that affect the pest attraction to the host plant. The mite Aceria carvi Nal. (Acari: Eriophyidae) becomes a serious problem in major caraway-growing areas in the Czech Republic (Rostislav et al., 2005).

Beneficial insects including predators, parasitoids, pollinators and visitors were more dominant than destructive insects for anise and caraway, while in contrary with cumin, the destructive insects were more dominant than beneficial insects during the two seasons. Caraway harbored the highest average number of predators followed by anise while the cumin was the lowest one during the two seasons. Pollinators and parasitoids were found in higher average number on anise than caraway during the first season, while the contrary in the second season, whereas cumin had the lowest average number of pollinators and parasitoids during the two seasons. Predators were dominant than pollinators and parasitoids on the three medicinal plants during the two seasons, except cumin during the first season the pollinators were more dominant than predators and parasitoids.

Table (2): Weekly average number of insects/25 double strokes of sweeping net inhabiting anise, caraway and cumin plants, at Abnoub district, Assiut Governorate, during 2007 and 2008 seasons

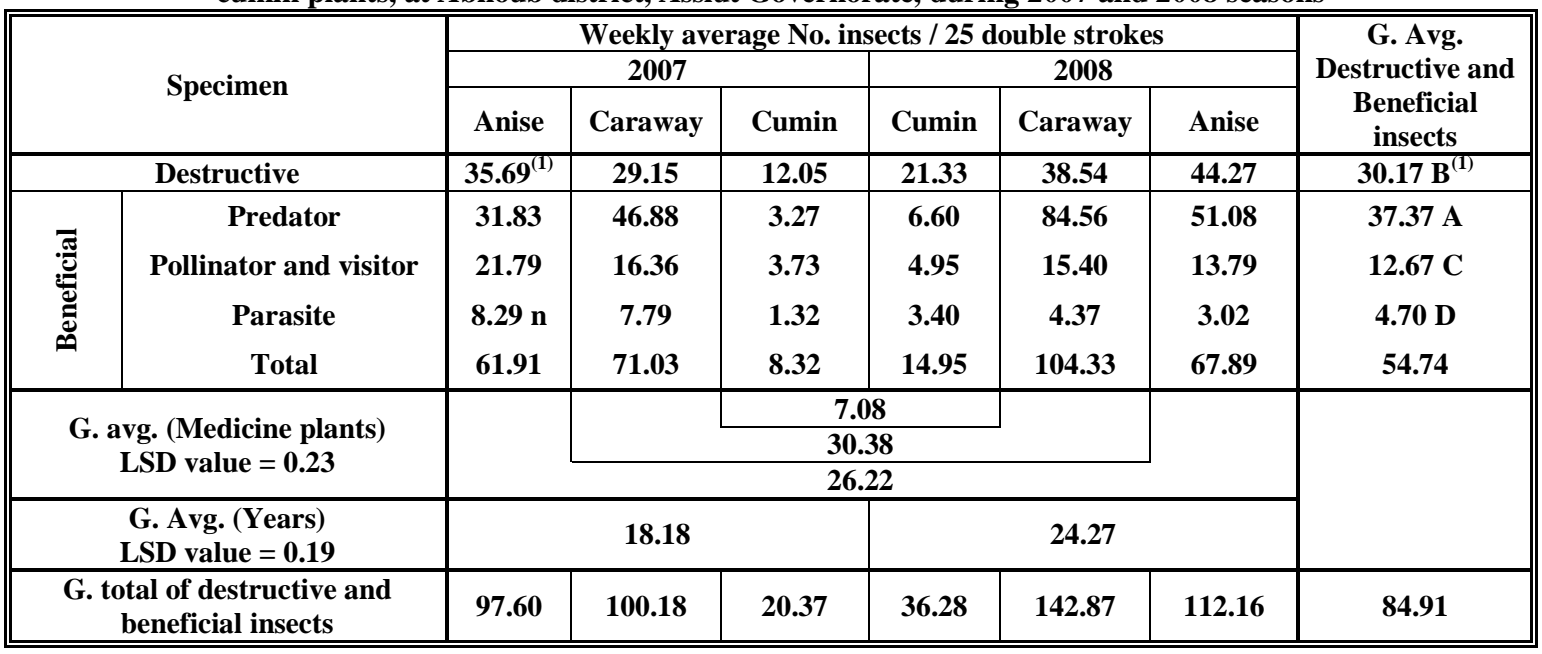

(1) Means followed by the same letter(s) do not significantly different at 0.05 level of probability. 
Seasonal fluctuations of destructive and beneficial insects on anise, caraway and cumin plants during 2007 and 2008 seasons are illustrated graphically in Figures (1, 2 and 3).

On anise, destructive insects started to infest the plants with relatively few numbers during the third week of February (11.25 and 15.5 insects/25 double strokes), then fluctuated until reached its peak of $(84.25$ and 131.5 insects/25 double strokes) during the second and third weeks of April for the first and second seasons, respectively. Thereafter, the number of insects declined in population through the next weeks until the end of season. Also, beneficial insects took the same trend, occurred in relatively few numbers during the third week of February (2.75 and 3.5 insects/25 double strokes), then fluctuated until reached its peak of $(210.25$ and 236.25 insects/25 double strokes) during the second and third weeks of April for the first and second seasons respectively. Predators and parasitoids recorded their peak in the second and third week of April during the two seasons, while pollinators had the peak during the second week of April in the first season and during the fourth week of April in the second season. The peak was followed by a decline in population through the next weeks until the end of season Fig. (1).

Activity curves of destructive and beneficial insects on caraway shown in Fig. (2) revealed that destructive and beneficial insects start to occur during the third weak of February in the two seasons, their populations fluctuated and reached their peaks at the third and fourth weeks of April (63 and 99.75 insects/25 double strokes) for destructive insects during the first and second seasons, respectively. Whereas, beneficial insects were reached their peak (217 and 334.25 insects/25 double strokes) at the fourth week of April in both seasons. In the first season, the peak of pollinators firstly reached (39.25) in the second week of April followed by the peak of parasitoids $(21.75)$ in the third week of April, while the peak of predators (169.25) lastly recorded in the fourth week of April. Whereas, in the second season, the peaks of predators (271.75), pollinators (44.75) and parasitoids (17.75) were detected in the fourth week of April.

Results of cumin graphically illustrated in Fig. (3) clearly indicated that the appearance of destructive and beneficial insects took place in the second week of February during the two seasons, then the population of destructive and beneficial insects fluctuated to reach their peaks in the first week of March for the first and second seasons, except beneficial insects reached its peak in the second week of April in the second season. These peaks were followed by a decline in the population throughout the next weeks. Predators, pollinators and parasitoids reached their peaks during the first week of March in the first season, while in the second season; the peaks are recorded during the fourth week of March for parasitoids and during the second week of April for predators and pollinators.

Regarding to the insects activity on the three medicine plants, it is clear that the peaks of destructive and beneficial insects were recorded during the blooming period. Also, results exhibited distinct compatibility between the abundance of the destructive species and their associated predators. These results may indicate the importance of the recorded predators as a biological control agent for regulating pests population on the medicinal plants (Abdel-Moniem and Abdel-Wahab, 2006). 

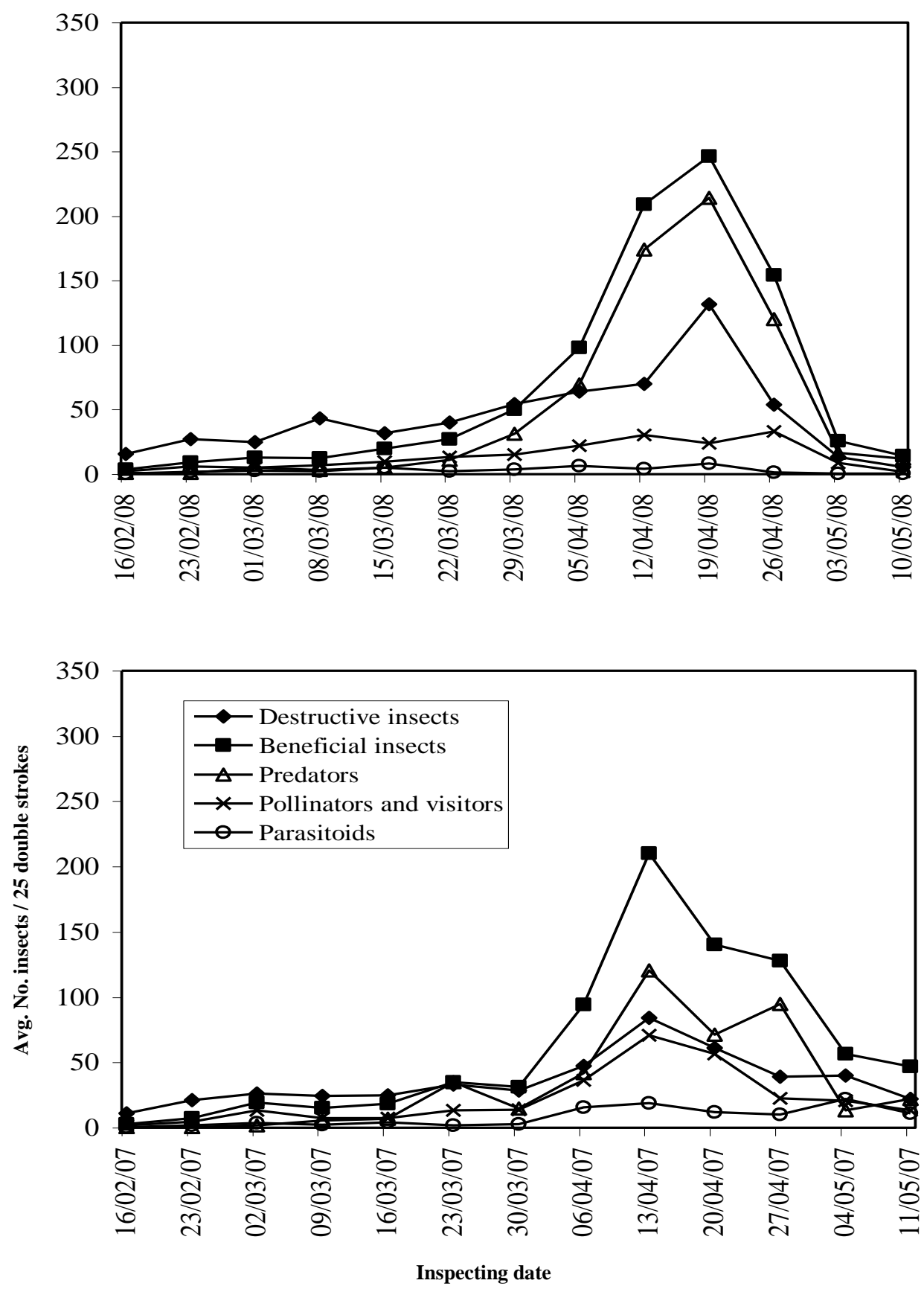

Fig. (1): Seasonal activity of destructive and beneficial (predators, pollinators and visitors, and parasitoids) insects on anise at Abnoub district, during 2007 and 2008 seasons 

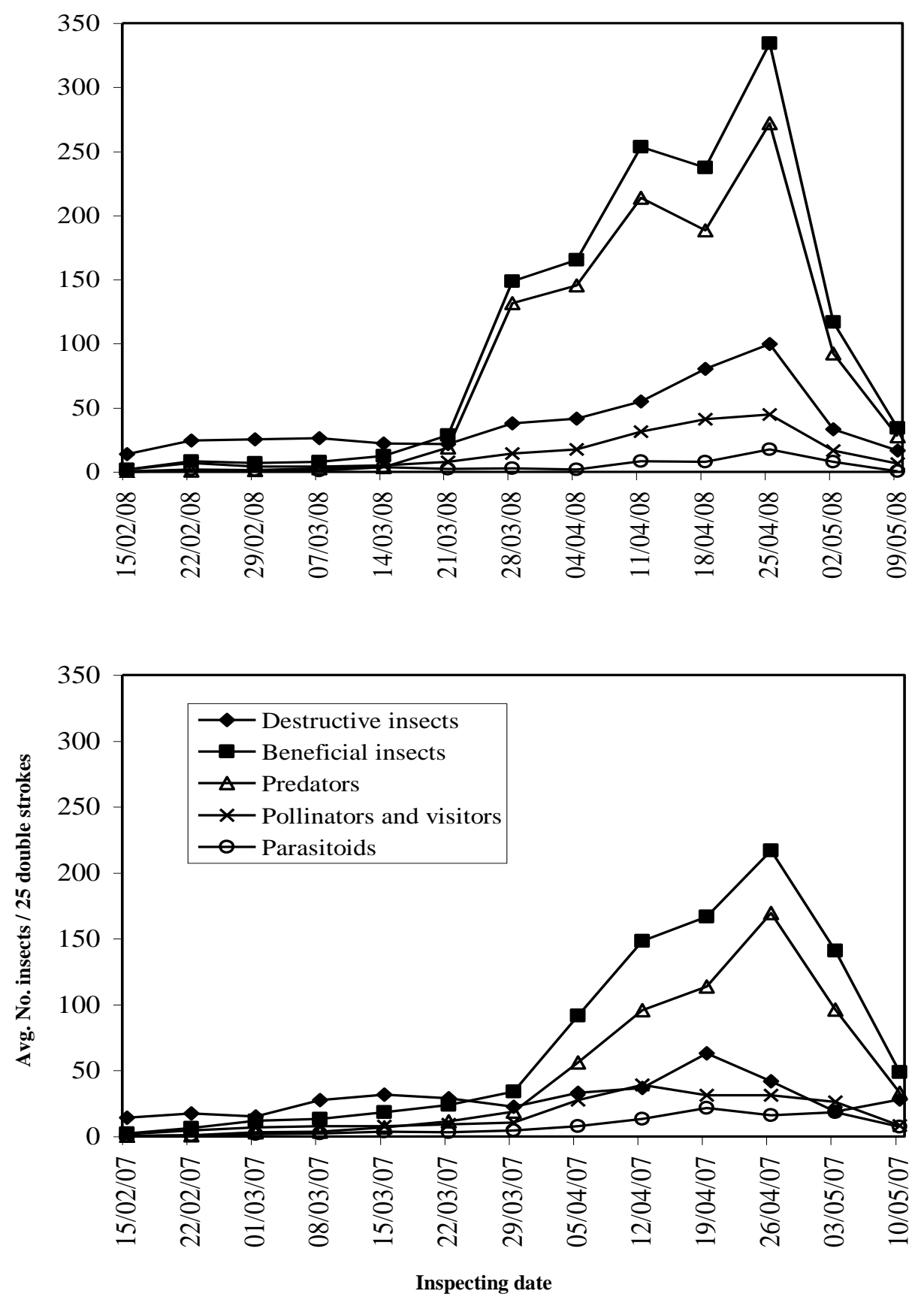

Fig. (2): Seasonal activity of destructive and beneficial (predators, pollinators and visitors, and parasitoids) insects on caraway at Abnoub district, during 2007 and 2008 seasons 

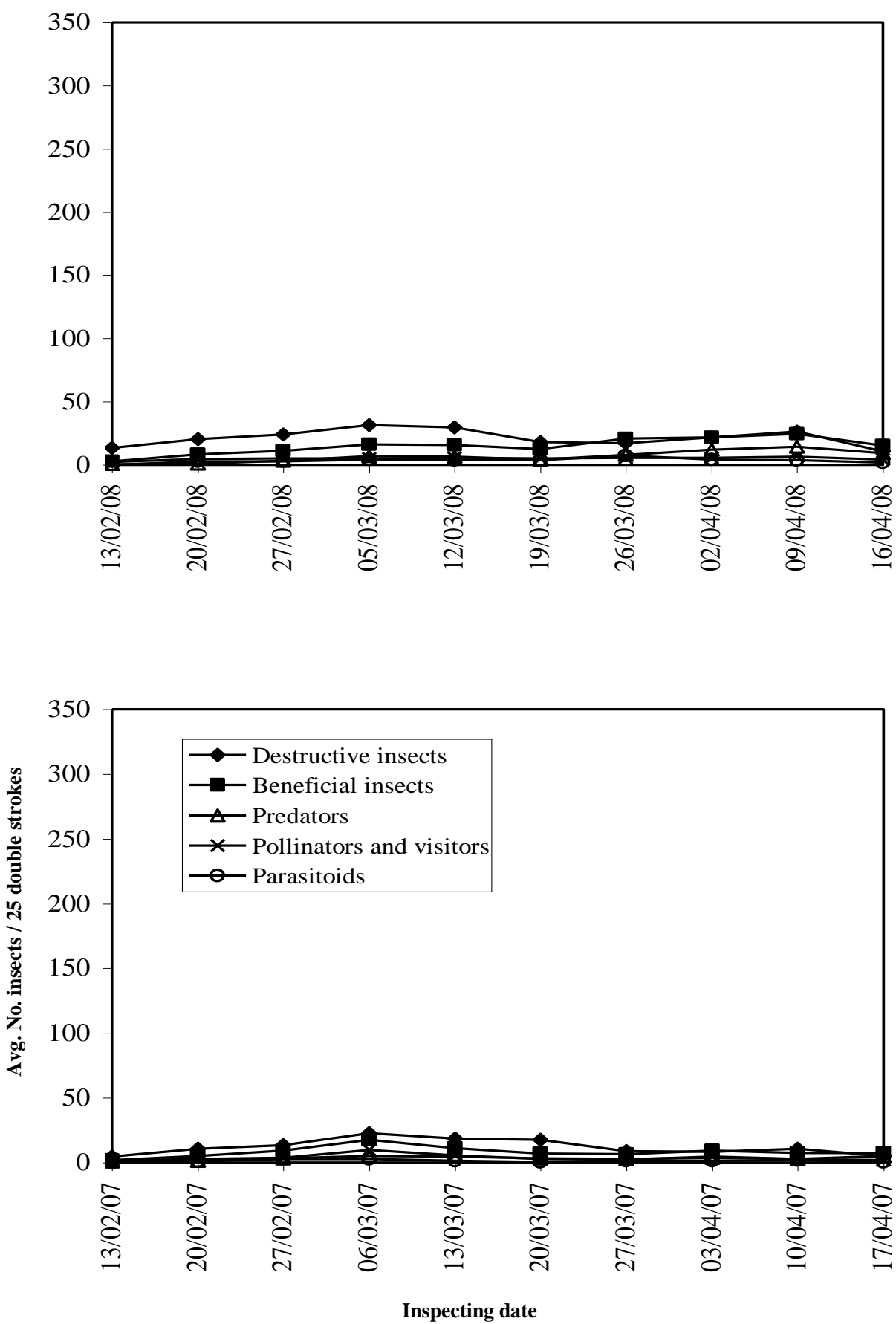

Fig. (3): Seasonal activity of destructive and beneficial (predators, pollinators and visitors, and parasitoids) insects on cumin at Abnoub district, during 2007 and 2008 seasons 


\section{REFERENCES:}

Abdel-Moniem, A. S. H. and T. E. AbdelWahab (2006): Insect pests and predators inhabiting roselle plants, Hibiscus sabdariffa L., a medicinal plant in Egypt. Archives of Phytopathology and Plant Protection, 39 (1): 25-32.

Abou Zaid, E. N., (1988): Aromatic and medicinal plants-their agricultural and medicinal products, El-Dar El-Arabia for Publishing, Cairo.

Abou-Elhagag, G. H., (1989): Field and laboratory studies on certain pests of medicinal and aromatic plants. M. Sc. Thesis, Fac. Agric., Assiut Univ.

Ali, A. G. (1988): Ecological and control studies on certain pests infesting medicinal and aromatic plants. Ph. D. Thesis, Fac. Agric., Assiut Univ. 297 pp.

Giry, H., (1980): A list of insects injurious of anise, Pimpinella anisum in the Aegean region: Turkiye Bitki Koruma Dergisi, 4: 49-57.

Hammoda, S. H., (1987): Ecological studies on certain pests associated with some medicinal and aromatic plants in Minia region. M. Sc. Thesis, Fac. Agric., Minia Univ.

Hussein, M. H. and S. A. abdel-Aal (1982): Wild and honey bee as pollinators of 10 plant species in Assiut area, Egypt. Zeitschrift für angewandte Entomologie, 93 (4): 342346.
Mesbah, H. A.; H. K. El-Sherif; K. S. Moursi and M. A. Mahmoud (1983): Survey of the pests infesting medicinal and ornamental plants in Egypt. Proc. $5^{\text {th }}$ Arab. Pesticide Conf. Tanta Univ., IV: 107.

Propov, P., (1972): Insect pests of medicinal plants in Bulgaria. III-Coleoptera. Rastenievdni Nauki, 9: 167-175.

Propov, P., (1973): Insect pests of medicinal plants in Bulgaria. I-Hemiptera. Rastenievdni Nauki, 10: 167-175.

Rashad, S. E., 1978: Utilization of non Apis bees as crop pollinators. EG. ARS., 66: 48 pp.

Rayadh, L., (2002): Producing and manufacturing aromatic and medicinal plants in Egypt, National planning Institute Diploma.

Rostislav, Z.; M. Kurowska; L. Kamenı'kova'; G. Z. Rovenska'; J. Havel and F. Reindl (2005): Studies on phenology and harmfulness of Aceria carvi Nal. (Acari: Eriophyidae) on caraway, Carum carvi L., in the Czech Republic, J. Pest Sci., 78: 115-116.

Shabbara, H. M. and A. E. Taha (2007): An economical study of the most important Egyptian aromatic plants. Journal of Applied Sciences Research, 3 (8):747-756.

Tiwari, K. C. and P. Joshi (1974): A record of some insect pests attacking medicinal plants at Ranikhet. Indian J. of Pharmacy, 36: 111-112. 
التركيب النوعي و التقلبات الموسمية لتعداد الحثر ات الضارة والنافعة المتو اجدة على ثلاث نباتات طبية في محافظة أسبوط عبد العليم جابر على، ماجد زاهي إمبارك، علاء الدين عبد القادر أحمد معهد بحوث وقاية النباتات- مركز البحوث الزراعية- جيزة- جمهورية مصر العربية

أجريت هذه الاراسـة بهدف معرفة التركيب النوعي للحشرات الضـارة والنافعة المتواجدة على ثلاث نباتات

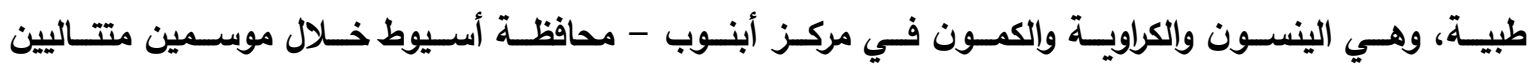

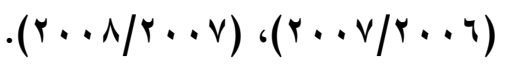

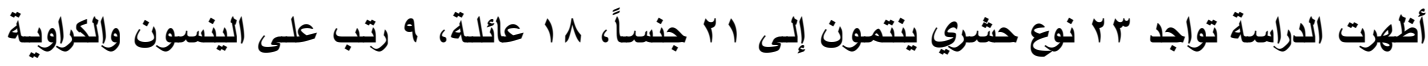

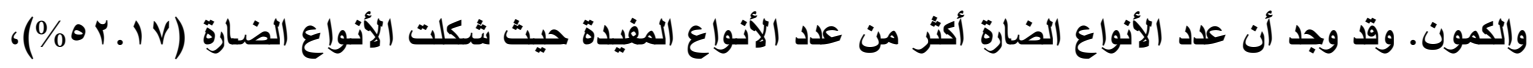

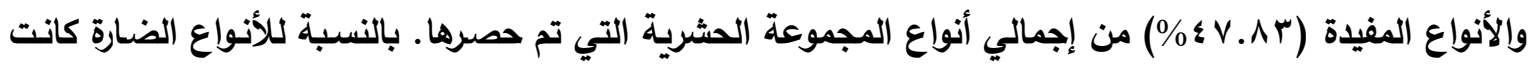
رتبتي متثابهة الأجنحة ونصفية الأجنحة تمثل المكون الأكبر من حيث عدد الحشرات الضارة التي تتبعها، في حين

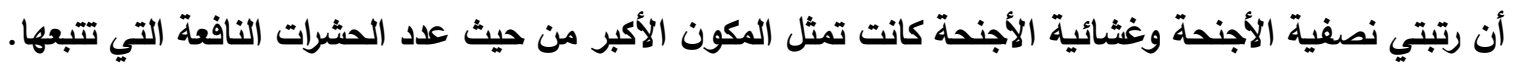

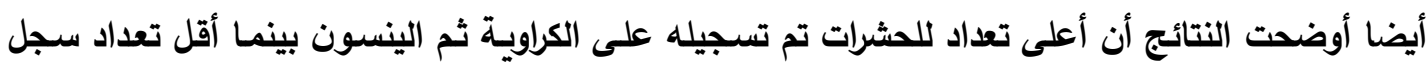

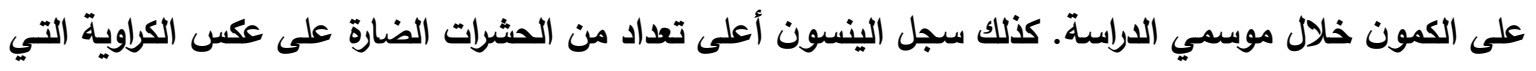

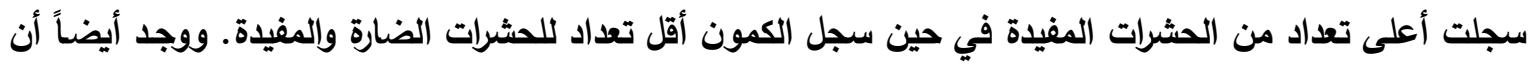

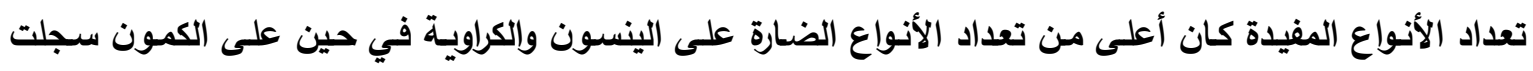

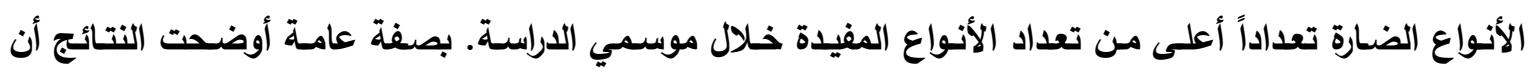

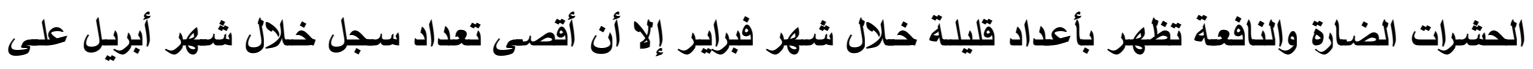
الثلاث نباتات. 